David Wilson

From the Caribbean to Craignish: Imperial Authority and Piratical Voyages in the Early-Eighteenth-Century Atlantic Commons

School of Humanities, University of Strathclyde, Lord Hope Building, 141 St. James Road, Glasgow G4 0LT

$+44(0) 1414448219$

david.wilson.101@strath.ac.uk 


\title{
From the Caribbean to Craignish: Imperial Authority and Piratical Voyages in the
}

\section{Early-Eighteenth-Century Atlantic Commons}

\begin{abstract}
:
Whereas seventeenth-century piracy has been recognized as an integrated component of the developing European Atlantic world, eighteenth-century pirates have been marginalized as an isolated group with little ties to landed communities. Such evaluations have stressed the heightened extension of state authority to the colonial theatre in the eighteenth century and, by doing so, have overlooked how pirates continued to interact with colonial actors operating in contested and unclaimed regions throughout the Atlantic commons. It is imperative that the Atlantic commons is given full consideration in any discussion of Atlantic maritime activity as it was within these expanses that inter-imperial, inter-colonial, and cross-border colonial actors converged. This article utilizes the piratical voyage captained by Howell Davies (and later Bartholomew Roberts) to demonstrate that it was within this commons that eighteenth-century piratical voyages were sustained and facilitated through the forced acquisition of supplies, through markets for plundered goods, and through the opportunities available for dispersing amongst landed communities at the end of expeditions. Continued connections between colonial denizens and pirates in the eighteenth century compels a reassessment of pirates' isolation to instead place them within the wider population of coastal traders, sojourning mariners, and marginal colonial settlers who existed both within and outside of the imperial framework espoused by state and colonial centers. Ultimately, this questions the overall ability of European states to regulate maritime traffic when vessels sailed out of sight of established colonial ports, and beyond the practical reach of imperial authority.
\end{abstract}

Keywords: pirates, Atlantic commons, imperial authority, inter-imperial connections

In February 1720, James Campbell of Stonefield, the Sheriff Depute for Argyllshire in Scotland, reported that an unknown vessel had been purposefully run aground in Loch Craignish on the mid-Argyll coast. Even more suspicious was the fact that the crew had deserted the ship, separated, and dispersed along several different roads. Campbell immediately sent search parties looking for the crew whilst going himself to search the ship. All he found on board, aside from some provisions, were scraps of a purposefully-torn journal. From the surviving notes of the journal, Campbell was able to determine with some degree of certainty that the vessel had come from North America's New England coast. Over the next few days, approximately thirteen of the crew were rounded up and arrested between Craignish and Dunoon. Adding to the peculiarities surrounding the event, Campbell wrote 
that moidores - a type of Portuguese gold coin - had been found on each man's person. The captured crewmembers were imprisoned in Inveraray jail for questioning. Another eight crewmembers were later caught at various locations between Argyll and Glasgow and brought back to Inveraray. At first the prisoners claimed that they had been bound from Dartmouth to Newfoundland, but that they had been forced to sail into Loch Craignish after their vessel, the Eagle, had been damaged in a storm. Campbell wrote that, aside from these basic details, each of the men's accounts were entirely inconsistent with one other. The reason behind this was quickly uncovered as, by the second examination, a number of the crew confessed to being pirates who had sailed under the commands of Howell Davies (or Davis) and Bartholomew Roberts, committing several piracies throughout the Atlantic Ocean. ${ }^{1}$

The nineteen surviving confessions of these crewmembers, who had joined the expedition at various different times and places, provide detailed description of a piratical voyage initiated by mutiny on board a small trading sloop off the coast of Hispaniola in September 1718. The pirates then plundered shipping in Cape Verde, Africa, and Brazil, before a portion of the crew separated in order to sail to the northern coast of Ireland under the command of Walter Kennedy, an Irish mariner who had been part of the voyage from the outset. Upon reaching Ireland, the crew intended to disperse and return to their homes throughout Ireland and England. During their return voyage, however, a storm drove them off course and into Loch Craignish. ${ }^{2}$ The confessions of the captured crewmembers, alongside victim testimonies and colonial reports concerning the same pirate crew, offer a rare insight into the progression of and strategies employed during a piratical voyage, and these insights challenge the predominant understandings of early-eighteenth-century piracy.

The activities of seventeenth- and eighteenth-century Atlantic pirates have inspired countless general histories which have focused on the narratives of the rise of the buccaneers 
in the mid-seventeenth-century Caribbean, the emergence of the Red Sea pirates in the 1690s, and the spread of Atlantic piracy after the Treaty of Utrecht (1713). In these studies, pirates are positioned as an 'other' in the Atlantic world and are observed as operating beyond the fringes of colonial society. ${ }^{3}$ Similarly, the social and cultural history of piracy, when not interwoven with general histories, has produced some radical accounts of anti-state mariners who rejected their nations to create seemingly democratic communities. ${ }^{4}$ The view that pirates rejected social and cultural norms to create an alternative social order has continued this theory of 'otherness' and, in the process, has misinterpreted the role that piracy played in the development of the Atlantic world. In comparison, scholars who have placed piracy within the wider political and economic framework of the British Atlantic world have revealed the extensive assimilation of pirates with landed colonial communities and the subsequent impact that these connections had on colonial development and imperial politics in the seventeenth century. By examining the widespread connections between colonial officials, traders, settlers, and pirates, these studies have shown that pirates operated on and within the fringes of colonial society rather than in opposition or resistance to it. ${ }^{5}$

While this research has firmly recast pirates as an integrated component of the seventeenth-century Atlantic world where piratical voyages were enabled and supported in colonial ports, the rise and decline of piracy in the period from 1716 to 1726 has not received the same level of scrutiny. Instead, it is suggested that eighteenth-century pirates operated within a hostile Atlantic world that no longer supported illicit maritime predation. From this perspective, piracy declined because of state manoeuvres that delegitimized peacetime commerce raiding, destroyed pirates, and stimulated the decline of colonial sponsorship of piracy. ${ }^{6}$ Hanna, in particular, has charted the process through which British colonies transformed from pirate nests into productive and self-sustaining communities that turned their backs on illicit maritime predation and became further connected to the metropole. This 
transformation occurred when colonial merchants gained legal access to markets that had previously fallen under monopolistic control, particularly the African slave trade, in the late seventeenth and early eighteenth centuries. As a result of these changes, Hanna argues, piracy was no longer a necessary and assimilated part of the Atlantic economy and could not be sustained. ${ }^{7}$ By stressing that pirate nests only transformed after peripheral communities accepted their place as part of a wider Atlantic empire, Hanna provides new weight to the argument that colonial support was central to the overall success of imperial policy as the British state was never in a position to effectively impose centralized administration over their Atlantic dominions. ${ }^{8}$ However, while it is clear that a more coherent and connected British Atlantic empire emerged as colonial communities became closely integrated with the metropole at the turn of the century, it is important not to overstate this point. Although colonial acceptance of state authority brought established port towns into a more coherent framework, this authority could not and did not extend far beyond the immediate shores of colonial centres.

Instead, as excellent work by Benton, Hancock, Jarvis, and Koot has established, neither state nor colonial centres were able to meaningfully dictate Atlantic maritime activity and trade throughout the seventeenth and eighteenth centuries. Even though state authority extended to many colonial ports in the early eighteenth century, Atlantic commerce continued to be driven by a multitude of individual transactions that remained decentralized, selforganized, and opportunistic, facilitated by transatlantic and trans-imperial markets and connections, irrespective of state mercantilist policies. Similar to the fact that the compliance and consent of each colonial centre was vital to the extension of state authority across the Atlantic, the obedience of maritime activity to the authority of colonial centres relied predominantly on individual behaviour. Colonists regularly chose to operate both within and outside of the legal commercial framework espoused by these centres as neither the 
metropolitan state nor individual colonies had the available resources to patrol and regulate maritime activity throughout the Atlantic. ${ }^{9}$ Consequently, the extension of imperial authority over maritime spaces was limited to specific sea lanes rather than extensive ocean zones. ${ }^{10}$ In fact, there was immense difficulty securing even the immediate proximities of established colonies against piratical attacks and illicit trade due to the severe lack of state-provided maritime defence. ${ }^{11}$ Simply put, there was little capacity for the regulation of maritime activity when vessels sailed beyond colonial shores. As such, traders frequently violated mercantilist restrictions in favour of profit and opportunity. ${ }^{12}$

This ad-hoc maritime activity took place in extranational maritime spaces that lay unclaimed or contested, particularly within the Greater Caribbean, where no European imperial officials resided to enforce imperial policy and restrictions; regions which Jarvis has termed the Atlantic commons. Here mariners periodically voyaged, and sometimes settled, in order to rake salt, salvage wrecks, hunt turtles, harvest marine resources, and smuggle goods. Pirates, too, exploited these spaces. However, the commons that pirates utilised existed not just in the contested and unclaimed regions of the Greater Caribbean, but also in the unprotected capes of North America, on the vulnerable coastlines of Africa, in peripheral European outposts throughout the Atlantic, and even in those spaces of the Indian Ocean where Atlantic mariners converged. To account for this, Jarvis' commons framework is utilised here in its broadest sense to refer to the predominantly littoral expanses where European imperial authority did not extend but where European subjects interacted and assembled. These commons, although fully integrated into the decentralized and selforganized Atlantic economy, existed beyond the oversight of state or colonial officials and, as such, were regularly overlooked in considerations of the Atlantic world. ${ }^{13}$

These spaces have also been overlooked within considerations of eighteenth-century piracy. For example, when considering the transformation of pirate nests, Hanna states that 
"where once pirates were accorded legitimacy or at least toleration, most colonial communities now considered them genuine outlaws." 14 Such assertions are accurate when referring to anti-piracy measures enacted from colonial centres in the early eighteenth century, but Hanna does not then evaluate how pirates' segregation from colonial ports transformed the methods and strategies that pirates employed to initiate, sustain, and end their voyages. Instead, he focuses exclusively on anti-pirate attitudes and, in the process, aligns with prevailing views that eighteenth-century pirates became entirely isolated from colonial communities. ${ }^{15}$ When examined from the perspective of the commons, however, it becomes evident that interactions and encounters between pirates and colonists continued beyond the shores of established colonial ports. Rather than halting connections between pirates and landed communities altogether, the transformation of pirate nests pushed such interactions more fully into the realm of the Atlantic commons where imperial authority did not and could not extend.

To date, there has been no detailed examination of how piratical voyages exploited the Atlantic commons to not only plunder but also interact with colonists and colonial communities. Even historians who have acknowledged that such interactions persisted well into the eighteenth century have not accounted for where and how this contact occurred. For example, Chet states that "Britons continued to engage in and support piratical and contraband trade despite efforts to delegitimize, outlaw, and suppress it in the eighteenth century" but does not then provide evidence or analysis of the means and methods of such support. ${ }^{16}$ One reason for this is the fragmented nature of evidence concerning earlyeighteenth-century piratical voyages in comparison to those of the seventeenth-century. That is not to say that seventeenth-century voyages are significantly easier to chart in their entirety, but that the ways in which piratical voyages predominantly began, outfitted, and concluded is more visible in the seventeenth century, when pirates were welcomed into and 
operated from various colonial ports, than in the eighteenth century, when voyages began and ended in the unobserved spaces of the Atlantic commons. As a result, the information concerning most eighteenth-century piratical voyages is incredibly piecemeal and hard to verify.$^{17}$ The voyage discussed within this article provides a rare exception as it can be charted from its beginning through to its multiple conclusions by making use of the crewmembers' confessions, which are more numerous and detailed than those concerning the majority of other piratical voyages. Furthermore, the detail provided within these multiple confessions has made it possible to compile a wide range of victim testimonies and colonial reports that concern this same crew, and which verifies and reinforces information provided by the captured crewmembers.

By charting the activities of the Eagle's crew, the methods and strategies employed throughout the duration of their voyage can be observed. These can then be compared and contrasted with the fragmentary evidence available concerning other piratical voyages to provide an overview of the ways in which pirates utilised the Atlantic commons to plunder, trade, and disperse. The continued assimilation of pirates with these spaces calls into question the dominant assessment that eighteenth-century pirates, as opposed to their seventeenthcentury counterparts, were an isolated collective that operated far beyond the fringes of colonial society. While such an examination offers new understanding of the progression of eighteenth-century piratical voyages, it also provides reflection on the sheer limitations of state and colonial authority over Atlantic maritime activity. Even when pirates were displaced from colonial ports in the early eighteenth century, they remained integrated with those maritime spaces that lay beyond the practical reach of imperial authority.

\section{Plundering the Atlantic commons}


When pirates were no longer welcomed in the port towns of the Atlantic, the means through which they could outfit, man, and arm vessels was limited. Although pirates' inability to operate from colonial ports has been employed by historians to demonstrate that colonial communities had transformed and rejected piracy, there has been only brief discussion of the methods that mariners then employed to undertake piratical voyages. ${ }^{18}$ Unable to outfit from colonial ports, pirates turned to spaces where they could gain the necessary resources to facilitate their operations. In particular, they sought provisions to sustain their voyage, recruits to bolster the strength of their crew, and better-equipped crafts with which they could hope to successfully engage and capture sizeable prizes carrying significant plunder. The Atlantic commons provided pirates with both the necessary recruiting grounds and a vast repository of provisions, supplies, nautical stores, and vessels which could be requisitioned for their purposes. By examining the regions and goods that Davies' and Roberts' pirate crew targeted, it is possible to understand how this piratical voyage, and others like it, endured and thrived within the Atlantic commons. That they were able to do so at a time when state and colonial centres were actively opposing piratical activity points to the limits of imperial reach within the maritime spaces that connected and surrounded their territorial possessions.

Throughout their expeditions, pirates primarily operated in those regions of the Atlantic commons where shipping congregated but that were either contested, unclaimed, or unprotected by the imperial powers. The overall shortage of naval vessels in the colonial theatre meant that these regions were not regularly patrolled and, even if naval vessels were sent in quest of pirates, their information was often outdated. On the occasion that pirates were encountered, large naval ships were frequently unable to pursue small pirate vessels through shoals and shallow waters and, as such, proved ineffective in suppressing them. ${ }^{19}$ Despite their overall failure to directly suppress pirates, the presence of naval ships stationed in ports, alongside their active convoying of trading vessels engaged in the most profitable 
colonial trades, meant that encountering and capturing vessels near significant colonial ports and throughout the principal colonial shipping routes proved problematic for pirates. ${ }^{20} \mathrm{In}$ response, they turned to those areas where trading vessels were employed but that were left vulnerable without armed convoys or coastal fortifications.

The activities of Davies' and Roberts' crew reflect this experience. After committing mutiny on board the Buck, a trading sloop outfitted from New Providence, off the coast of Hispaniola in September 1718, the crew primarily cruised on the uninhabited and undefended stretches of the Hispaniola coastline, reportedly voyaging to similar locales in Cuba. During this time, they preyed on small coastal vessels which offered little or no defence rather than attempting to seize larger shipping near the defended ports. ${ }^{21}$ From Hispaniola, Davies and the crew voyaged to Maio in the Cape Verde Islands. Although under Portuguese authority, Maio was an undefended peripheral island where foreign traders from European and colonial waters regularly sailed in the seventeenth and eighteenth centuries to take advantage of the island's sizeable saltpans. The lack of defence at Maio meant that it also became a regular rendezvous for pirates and privateers who preyed on shipping loading salt at Maio as well as commercial vessels entering and exiting the nearby island of Santiago. ${ }^{22}$ Next, Davies' crew turned to Africa where they committed depredations in Gambia River, Sierra Leone, Anomabu, and the Portuguese islands of Príncipe and Annobón in the Gulf of Guinea and gained supplies, recruits, and superior vessels. ${ }^{23}$ During their time on the western African coast, the crew faced little opposition as European warships rarely patrolled the expanses of the African coast and, aside from the numerous European forts positioned along the Gold Coast, there was little effective defence throughout the majority of the coastline. This meant that slaving vessels proved particularly vulnerable to piratical attacks. ${ }^{24}$ 


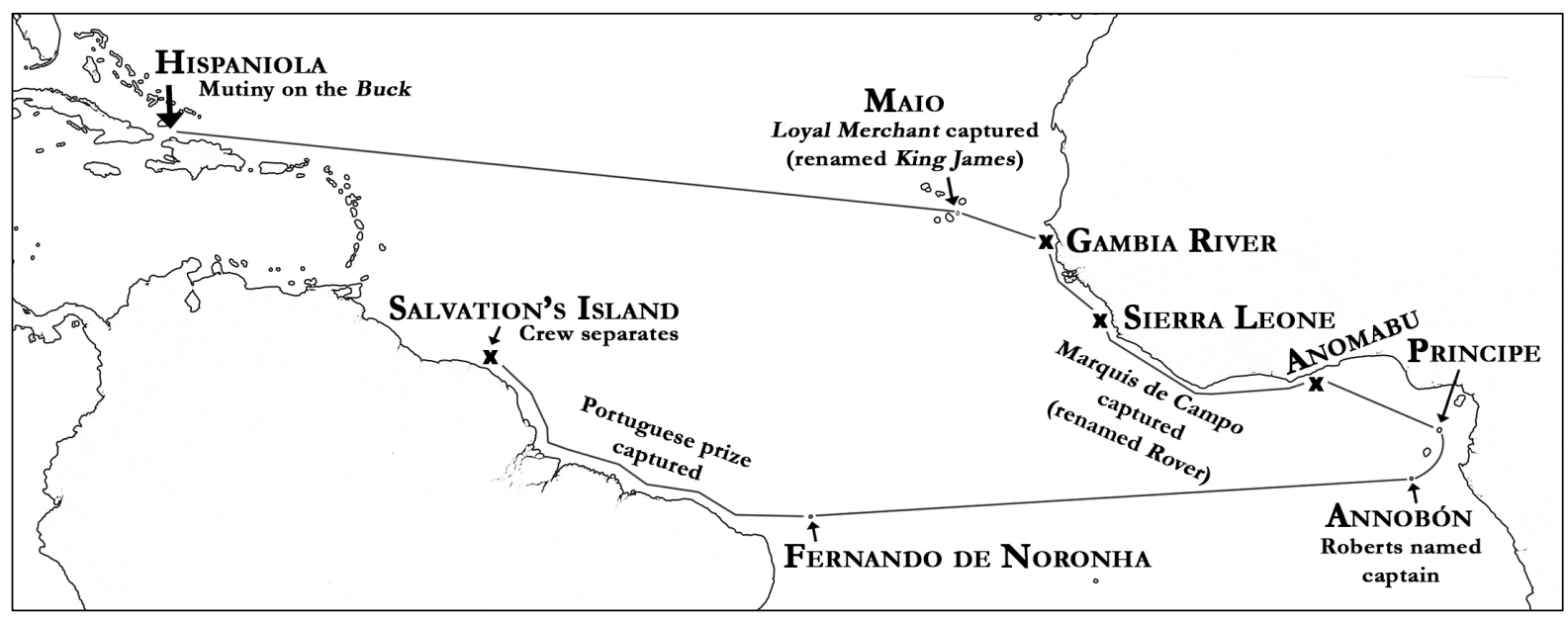

Figure 1. Map showing the pirates' expedition from Hispaniola to Salvation's Island

Throughout the majority of their voyage, the pirates had targeted shipping in exposed regions where they encountered little or no opposition. These spaces lay either unclaimed or undefended by imperial and local powers and instead were well-trafficked littoral commons where Europeans vessels could gather resources and transact with resident brokers, whether European or African, away from the conclaves of imperial control. Likewise, these were regions where European traders could expect little protection from external threats. On turning to Brazil, however, Davies and the crew targeted Portuguese treasure ships which were well-armed, sailed in great fleets, and were convoyed by Portuguese warships. ${ }^{25}$ This seems to have been their ultimate target. The pirates had purposefully utilized undefended shipping routes throughout the Atlantic commons as the means through which to outfit and prepare for a voyage against better-defended prizes in richer cruising grounds by concentrating on the acquisition of three key assets: supplies, recruits, and a superior vessel.

After seizing the Buck, the pirates spent approximately five or six weeks in and around Hispaniola, where they plundered at least three sloops and several small vessels described as being "of no consequence." 26 At this point, the crew were not seeking valuable prizes but, instead, plundered these vessels for provisions and supplies which they needed to 
stockpile in order to undertake their intended cruise to Africa. ${ }^{27}$ In fact, throughout this entire voyage, the majority of vessels that were taken by the crew were plundered for their provisions before being dismissed without further harm. ${ }^{28}$ For example, of the twenty-one reported piracies in which Davies' crew were involved on the west coast of Africa: fifteen vessels were plundered and dismissed, three were burned, and three were carried off by the pirates. ${ }^{29}$ John Bennett, captain of the Robert and Jane which was taken by the crew at Maio, reported that the pirates removed "the greatest part of her Cargoe which consisted of several Chests of fire Arms, several Bails of India Goods \& Perpetuanas, severals Casks of Rum, some Powder, \& all his ships Gunns being eight in number." 30 Other goods that the pirates plundered included clothes and water, alongside whatever money and valuable trading goods could be found on board. Likewise, the crew looted supplies from the Royal African Company's (hereafter RAC) factories in Gambia River and in Sierra Leone which were then burned and destroyed. These supplies, particularly provisions and water, were vital for ensuring the sustenance of the crew during their voyage whilst firearms and powder provided additional firepower which could be utilized to enact further piracies. While money and trading goods were also seized and divided between the crew, this was not the primary motivation behind these depredations. ${ }^{31}$ The pirates were gaining the means through which to continue their voyage and undertake the passage to richer cruising grounds. Importantly, it was not just supplies that the crew sought. Although the majority of the pirates' depredations took place on the African coast, it was not the specific cargoes of slaving vessels that the crew desired. Instead, Africa provided a necessary sojourn for pirates seeking recruits and larger ships.

For almost every vessel that was taken by Davies' crew, there is an account that men from the captured vessel either voluntarily joined or were pressed into the pirate crew. Of those members of the crew who were apprehended at Argyll, each had been taken at various 
times from different ships. For example, Rodger Hughs, a sailor from Whitechapel, had sailed from London to New Providence on the Buck and was on board when the mutiny occurred whereas William Fenton, a shipwright from Wapping, was taken whilst on board the Morris sloop at Anomabu in Ghana. ${ }^{32}$ Another two vessels were seized at Anomabu, the Royal Hind and Princess, and it was reported that the pirates took "as many of their Crew as they thought fit for their purpose" before dismissing the rest with their vessel. ${ }^{33}$ A number of other crewmembers were recruited or pressed from vessels seized at Hispaniola, Maio, Gambia River, and Sierra Leone. ${ }^{34}$

Although all of the crewmembers apprehended at Argyll claimed to have been forced into the pirates' service, it is clear that this was not entirely the case. Distinguishing between those who were forced and those who were not is problematic, and sometimes impossible, as those who were forced to join and attempted to resist were often threatened and beaten until they became active members of the crew. However, the exceptional amount of evidence concerning this individual voyage makes it possible to confirm with a relative degree of certainty that some of those caught in Argyll had clearly attempted to resist participating in the crews' actions, either through fleeing when on shore or by refusing to assist during engagements, while others had willingly joined when their ships were taken and later claimed they had been forced in a bid to gain mercy. ${ }^{35}$ One clear case of this is John Clerk, a sailor from Bangor in the northeast of Ireland, who claimed he had been forced into the pirates' service at Hispaniola whilst on board a Philadelphia trading sloop. The testimonies of both Archibald Murray and Rodger Hughs, who were present on the Buck during the mutiny, refute this claim and suggest that Clerk was one of the original mutineers. It seems Clerk had in fact joined the crew at New Providence, and it is likely that he was a former New Providence pirate who had accepted amnesty when the British state offered a blanket pardon to any pirates who surrendered between September 1717 and July 1719. ${ }^{36}$ Moreover, a "John 
Clarke" appears in a list of New Providence pirates who had surrendered themselves to a Royal Navy captain in July 1718 and it is probable, although by no means certain, that this was Clerk. ${ }^{37}$ Whether he was an active mutineer or a pardoned pirate forced back into service, Clerk had attempted to conceal his presence on board the Buck at the time of the original mutiny in order to further his defence and advance his potential prospects of gaining mercy. Clerk's case is just one example of the difficulties involved in establishing the truth behind many pirates' testimonies.

In this case, it is clear that a number of sailors both signed onto and were forced into Davies' crew in various undefended locales throughout Africa. Whereas the mutiny had started with just thirteen men, the crew had grown in size to between 100 and 130 men when the pirates left the African coast bound for Brazil in the latter half of $1719 .{ }^{38}$ There was a variety of reasons why mariners may have chosen to join Davies' crew from lawful trading voyages throughout the Atlantic commons, including the harsh discipline of individual merchant captains, meagre wages, and the promise of future economic gain. ${ }^{39}$ While crewmembers were also recruited in Hispaniola and Maio, Africa provided the primary recruiting ground for Davies' crew. Indeed, sailors engaged on slaving voyages proved particularly willing to join pirate crews as an alternative to their present employment in the early eighteenth century. One Royal Navy captain, Francis Willis, who was dispatched to Africa in 1720, reported that mariners in Africa were "ripe for piracy" but could not judge whether this was "occasion[e]d by the Masters ill usuage or their own natural inclinations." 40 As discussed by Janzen, there were similar discussions of pirates who voyaged to Newfoundland in the 1720s in order to refit and where stragglers, keen to escape the harsh conditions of Newfoundland or who had been indebted due to unproductive fishing seasons and unpaid wages, were recruited into pirate crews. ${ }^{41}$ Whether forced or otherwise, recruits gained from lawful trading voyages and peripheral communities throughout the Atlantic 
commons were vital to bolstering pirate crews and enabled them to operate larger vessels and pursue greater prizes. ${ }^{42}$

Alongside restricting access to supplies and recruits, seclusion from colonial ports meant that pirates did not have access to shipping outfitted for the express purposes of piratical cruises, but instead needed to acquire shipping elsewhere in order to begin their voyages. In the early eighteenth century, mutiny provided one of the principal means to achieve this. Yet, successful mutinies often occurred in trading vessels of limited tonnage whose smaller crews were easier to overpower by revolting crewmembers. In order to target lucrative shipping in well defended locales, pirates needed to then capture a larger vessel that could be outfitted with bigger crews and greater firepower. Such activity has been recognised in previous studies, but these have provided little specific evidence or analysis of the step-bystep progression that occurred from pirates' acquisition of small crafts to the eventual procurement of vessels strong enough to attack significant prizes. This is primarily because the fragmentary evidence surrounding eighteenth-century piratical voyages means that tracking and verifying such progression on a case-by-case basis is problematic. ${ }^{43}$ However, there is enough evidence to trace the sequence of this crew from one vessel to another throughout their voyage, and this provides new insight into the methods of early-eighteenthcentury piracy.

The mutineers on board the Buck were reported to have been previously pardoned pirates from New Providence. It seems that they exploited the opportunity to join the trading voyage to Hispaniola as the means through which to gain a vessel to begin another piratical cruise. ${ }^{44}$ The Buck was a small vessel of seventy-five tons that mounted only six guns. It was suitable for plundering vessels of similar size and strength, particularly vessels employed on inter-imperial and inter-colonial trade on colonial coasts, but lacked the firepower that could be utilized against ships of greater tonnage carrying substantial plunder. ${ }^{45}$ As such, they 
turned to Africa in quest of large poorly-defended slaving vessels that could be outfitted for their purposes. This was communicated to the Admiralty in 1720 by London-based slave traders who informed:

It hath been found by fatal Experience That the pirates when they are pursued or forsake the West Indies, do not faile to come to the Coast of Africa, in order to supply themselves with good sailing ships well furnished with Ammunition, provisions, \& stores of all kinds, fitt for long Voyages. ${ }^{46}$

In 1719, when Davies and the crew were cruising in Africa, a range of vessels were employed in slaving voyages on the African coast. These varied considerably in type and size from small sloops of thirty tons to large frigates of up to 400 tons. The number of cannons recorded on these varied anywhere between two and twenty-eight guns, and it is likely that larger vessels mounted at least thirty-six guns. ${ }^{47}$ The pirates sought to upgrade their small craft to one of these vessels in order to allow for a larger crew and superior firepower.

However, to successfully engage and capture slaving vessels, particularly those mounted with a large number of cannons, the pirates first needed to transfer to a better-equipped vessel than the small Buck sloop. The Cape Verde islands provided an exposed locale in which such a vessel could be captured en route to Africa. Whilst at Maio, the crew of the Buck captured three vessels: the Loyal Merchant of Liverpool, the Merry Thought of Lisbon, and the Robert \& Jane of London. The Merry Thought and Robert \& Jane were dismissed while the Loyal Merchant was kept and renamed the King James. ${ }^{48}$ The tonnage of the King James is not recorded but it was described as a large ship. ${ }^{49}$ Whatever its size, it was clearly a superior ship to the Buck and capable of carrying more guns and a larger crew. Furthermore, whilst in the River Gambia, the crew employed the increased firepower of the King James to 
successfully attack and destroy the RAC's fort in the river, taking between nine and twelve cannons which were subsequently mounted on the King James to again increase the pirates' overall strength. ${ }^{50}$ The next ship captured and outfitted was the Marquis de Campo, a frigate belonging to Ostend, which was taken between Sierra Leone and Anomabu. This was a small frigate of 100 tons, which seems to have been a similar size to the King James, but was deemed "the better ship mounting about Thirty two Guns." ${ }^{51}$ As such, the full crew transferred from the King James to the Marquis de Campo, renamed the Rover or Royal Rover. ${ }^{52}$ The Rover, stocked with provisions, manned with a large crew of voluntary and involuntary recruits, and outfitted with at least thirty-two cannons, proceeded to Brazil in quest of a wealthy prize.

From the original mutiny on board a small sloop off the coast of Hispaniola, the pirates had continually increased in number whilst stocking up on necessary supplies and trading up to larger vessels captured throughout the Atlantic commons. It is uncertain whether the objective had always been to attack the Portuguese treasure fleet but it is clear that the pirates' basic intention was to proceed to a location where they could pursue a substantial prize. This was also the case of other pirate crews who cruised on the African coast and then continued to the Indian Ocean. ${ }^{53}$ From Africa, the crew of the Rover - who had elected Bartholomew Roberts as captain after Davies had died at Príncipe - stopped at the island of Fernando de Noronha and then sailed along the Brazilian coast for about six weeks before encountering a Portuguese treasure fleet of forty-two ships, convoyed by two men of war. The pirates captured two vessels from the Portuguese fleet, one of which was a substantial ship of 400 tons carrying an abundance of moidores and gold dust. ${ }^{54}$ The plunder from this prize was estimated to value between sixteen and eighteen thousand pound, and proved to be one of the most substantial hauls of the early eighteenth century. ${ }^{55}$ The provisions, recruits, and superior ship that the pirates had accumulated throughout their 
voyage proved vital to this success. The supplies enabled the pirates to cruise on the Brazilian coast for six weeks in anticipation of the treasure fleet, while their overall strength facilitated success when the fleet was encountered. The captured Portuguese treasure ship had been mounted with at least thirty-two guns which meant that it matched the Rover in firepower and likely contained a similar number of men. In order to quickly engage and capture the Portuguese treasure ship before the warships and other vessels of the fleet came to their aid, the pirates needed a vessel of similar strength that could hastily subdue their prize. In this case, the Portuguese ship surrendered after one broadside and a volley of small shot while only one man was killed and two wounded from the pirate's crew. ${ }^{56}$ Likewise, after capturing the vessel, the pirates immediately fled with their prize to Salvation's Island (referred to as Triangles) off the coast of French Guiana, successfully outrunning the Portuguese men-ofwar that pursued them. This would not have been achievable without a sizeable crew that was capable of sailing both vessels.

There were few other comparable successes in this period as the majority of pirate crews either did not voyage to these better-defended locales or were unsuccessful when they did. It is notable that the other two significant prizes reported during the early eighteenth century were taken in the Indian Ocean by pirates who had undertaken a similar voyage to Davies' crew. Christopher Condent, who had sailed in the Caribbean before directing to the Indian Ocean, captured the Faza Ramance, a rich Arab trader travelling from Jeddah, while Richard Taylor and La Buse, who had sailed in consort with Davies at Sierra Leone, captured the Nossa Senhora do Cabo, a large Portuguese vessel carrying the Viceroy of Goa and a substantial quantity of treasure back to Portugal. In all of these cases, the pirates had benefitted through the supplies, recruits, and shipping that could be plundered from commercial vessels and locales throughout the Atlantic commons. ${ }^{57}$ 
It is important to recognize that even those crews that did not undertake lengthy voyages to Brazil or the Indian Ocean, and instead focused on small-scale raids on shipping in the Caribbean Sea and North American coastline, also utilized the Atlantic commons in similar ways. Rather than seeking one large prize in distant waters, these crews exploited the unprotected expanses of the Atlantic to gradually profit through multiple piracies on small trading vessels. They concentrated their efforts in contested and vulnerable spaces such as the Bahamas, Bay Islands, and Virgin Islands where traders engaged in a variety of enterprises and also preyed on unprotected shipping near unguarded capes and along vulnerable stretches of coastline in North America. At the same time, they used these extranational maritime spaces to supply, recruit, and seize vessels that were deemed better-suited for their purposes. $^{58}$

Therefore, the Atlantic commons was exploited to initiate and sustain piratical voyages, whether for long-ranging voyages or localised attacks, and this highlights both the specific impact that the closure of colonial ports had on piratical voyages as well as the alternative opportunities available to them in spaces outside of imperial control. By looking purely at the depredations outlined here, however, it could be argued that pirates were acting in opposition to maritime activity throughout the Atlantic commons. In this regard, they could be considered as an 'other' in this space because they indiscriminately attacked shipping of all nations and, as a result, were rejected by the majority of established colonial centres. Doing so, however, would be to overlook the fact that piracy reflects the very nature of Atlantic maritime activity which was dictated not by state power but through the ad-hoc decisions of groups and individuals who exploited this vast maritime theatre to make their fortune. ${ }^{59}$ This is demonstrated not only by those mariners who mutinied or willingly joined pirates from lawful voyages, but also by the wide range of actors throughout the Atlantic who aided and abetted pirates in order to reap the benefits of their plunder. 


\section{Trading in the Atlantic commons}

Despite the transformation of pirate nests charted by Hanna, and the apparent isolation of pirates advanced within the wider historiography, there are several accounts of commercial transactions occurring between pirates, traders, and settlers in the early eighteenth century. This trade predominantly took place in the remote inlets and islands of the Atlantic commons, where colonial traders and local settlers rendezvoused with pirates and took advantage of a high-risk, opportunistic trade. Similar to inter-imperial and inter-island trade, this was a largely invisible trade, taking place without any centre, and occurring in-between the spaces of state or colonial oversight. As such, the volume and scale of commerce between pirates and colonial actors is difficult to measure. ${ }^{60}$ Nevertheless, it is possible to demonstrate that this trade did occur and that it was potentially endemic. This challenges the dominant view that eighteenth-century pirates operated without any support from colonial communities, while also providing novel demonstration of the nature of Atlantic maritime activity when vessels sailed beyond and in-between imperial centres.

Davies' crew traded with peripheral actors on at least two separate occasions and it is almost certain that there were additional transactions that went unrecorded. In April 1719, Robert Plunkett, the RAC agent for Sierra Leone, stated:

That ye pirates have meet $w[i]$ th such reception there [Sierra Leone] that it is become a place of Rende[z]vous for them there being so many Rascalls on shore that assist them w[i]th Boats \& Cannoes to bring their goods on shore and likewise Encourage them in all Manner of Villiany. ${ }^{61}$ 
The pirates complained of were the crews of Cocklyn, Davies, and La Buse who sailed in consort in Sierra Leone for several weeks. ${ }^{62}$ During this time, it is clear that a number of transactions had taken place between the pirates and resident British traders who maintained private commercial outposts on the shores of Sierra Leone River. ${ }^{63}$ It was reported that these traders sent boats to the pirates' ships which returned "loaden with goods \& Liquors." 64 Although some of the masters of the plundered vessels recovered a portion of their goods from the traders after the pirates had departed, it was suspected that the traders kept the bulk of the plunder. ${ }^{65}$ The second occasion reported occurred at the Portuguese island of Príncipe where Davies traded with the Portuguese. One of the crewmembers reported that Davies landed multiple times at Príncipe with a number of his men and, on at least one occasion, returned with provisions. ${ }^{66}$

It was Davies' dealings at Príncipe that led to his death. There are conflicting accounts as to what transpired but a disagreement arose either between Davies and the governor, or between Davies and the inhabitants of the island, which resulted in the inhabitants firing upon and killing Davies and the crewmembers who had accompanied him. ${ }^{67}$ Peter Cheap, who served as supercargo on board the Loyalty of Glasgow which visited Príncipe shortly after the pirates had departed, reported that the governor of Príncipe had divulged that the conflict occurred after he had required money for the provisions he had given Davies. This had motivated Davies to land armed men and resulted in the skirmish. ${ }^{68}$ Another account appeared much later in a publication by William Snelgrave, who was captain of a ship captured by Davies in Sierra Leone, which claimed that the governor launched a surprise attack on the pirates after he feared repercussions for trading with them. ${ }^{69}$ Whatever the case, it is apparent that prior to the skirmish the Portuguese governor had at least suspected that Davies and the crew were pirates but still permitted them to purchase provisions at Príncipe. As Príncipe was under the direct authority of the Portuguese and ruled 
by an appointed governor, it cannot be considered part of the contested or unclaimed Atlantic commons. Yet, that the governor was willing to transact with pirates when they arrived at the island is indicative of the fact that there remained peripheral European outposts throughout the Atlantic where imperial officials and inhabitants were willing to trade with pirates when it proved beneficial. Such interactions remained, for the most part, hidden from official record so that it is rare to uncover evidence of this commerce. Indeed, the only reason that verifiable evidence survives of this specific transaction is because such interactions had led to conflict between the pirates and the inhabitants, and this was reported in various sources. However, when the evidence regarding this voyage is paired with comparable anecdotal evidence, the persistence of commercial interactions between pirates and colonists, whether carried out in the ports of peripheral outposts or throughout the Atlantic commons, becomes harder to disregard as exceptional.

There are reports of various groups of Europeans actively aiding and supporting pirates throughout the Atlantic and Indian Oceans in the early eighteenth century. Traders from established colonies, including Jamaica and Bermuda, who were engaged in interimperial and inter-colonial trades were reported to exchange goods for piratical plunder when the opportunity arose in spaces beyond colonial ports. ${ }^{70}$ This was outlined by the lieutenant governor of Bermuda, John Hope, who wrote "the great good of these people (is what they call) a maroon life: This is wandering from one uninhabited Island to another (in their sloops), fishing for wrecks, and trading with pyrat's, and living not like animals that are imbued with reason. ${ }^{71}$ " In an earlier account, he had reported:

There is such a correspondence betwixt the pyrates and those people that go from hence [Bermuda] (as well as from the other Plantations) to those Islands where they 
pretend to rake salt, that except there be some effectual remedy fall[e]n upon to break off that intercourse these parts will always swarm with those vermin. ${ }^{72}$

It is important to note that reports of this illicit trade were often given without specific evidence and were written by colonial officials and mercantile actors who used these accounts as a means to vilify local opposition, although there is enough additional evidence to suggest that such a trade did take place. Alongside this ship-based trade, there is existing evidence that pirates transacted with peripheral outposts and remote settlements. In addition to the account of Davies trading at Príncipe, there is at least one other account of pirates gaining provisions at marginal European outposts when the crews of the Cassandra and Victory traded with merchants from the Dutch fort at Kochi on India's Malabar coast. ${ }^{73}$ Other accounts relate that Europeans who had settled and cultivated land in sites of little state or colonial oversight, such as the outlying islands of the Virgin Islands, were active accomplices of pirates. ${ }^{74}$

It is difficult to assess how far engaging in this commerce was a choice made by colonial traders and settlers or whether this was a forced trade driven by apprehensions of the superior strength of pirates. For example, Captain Knott, whose vessel was taken in the Caribbean, reported that pirates plundered all of his sea stores and, in recompense, gave him sugar, tobacco, and moidores. This appears to be a reliable account as Knott did not attempt to conceal these dealings, but instead immediately reported it to the Virginian governor on arrival and relinquished the plundered goods. ${ }^{75}$ On the other hand, there is substantial proof that traders who were engaged in the Madagascan slave trade proactively transacted with the few sets of pirates who voyaged to the Indian Ocean in the early eighteenth century. ${ }^{76}$ Overall, the available evidence provided by first-hand testimonies, pirate depositions, and the accounts of individuals who were caught trading with pirates suggests that colonial and 
peripheral actors were both complicit and forced at different times on a case-by-case basis. ${ }^{77}$ Although the volume of this trade is impossible to measure, it is clear that wherever pirates travelled, there was a contingent of traders and inhabitants who were both willing and forced to trade with them. In turn, these abettors benefitted from the exorbitant prices they could charge pirates; they were able to gain a share of illicit plunder without the risks of undertaking a piratical voyage. ${ }^{78}$

The fact that contact persisted between pirates, colonists, and settlers despite the decline of open colonial sponsorship at the turn of the century provides a clear demonstration of the limitations of state and colonial authority over Atlantic maritime activity. While Royal Navy vessels voyaged in search of pirates, and colonial centres outfitted vessels to counteract pirates impacting local trade, colonial traders continued to transact with pirates in peripheral locales. This interplay between compliance and defiance is exemplified by the attempts to protect Jamaican trade from pirates in the 1720 s. In 1722, the Jamaican assembly, with the full support of the governor and council, passed an act which provided funds to employ a sloop to guard the Jamaican coast from pirates. ${ }^{79}$ In 1724 , it was reported that outfitting guard-ships cost Jamaican planters "an annuall Expence of $£ 5000$ a year \& sometimes Double." ${ }^{\prime 80}$ While private guard-ships were engaged to protect the immediate coastlines, Royal Navy vessels assigned to Jamaica actively convoyed Jamaican merchant ships employed in the profitable Anglo-Spanish contraband trade which centred on the Honduran coast. Jamaican merchants requested Royal Navy protection after pirates operating from the Bay Islands - Guanaja, Roatán, and Útila - posed a significant threat to this trade; the islands lay in close proximity to Trujillo, one of the key contraband entrepots. ${ }^{81}$ At the same time, Ellis Brand, a Royal Navy captain stationed at Jamaica, complained that pirates at the Bay Islands were supported by individuals in Jamaica who "send from hence to there reliefe", a practice which he feared was widely practiced. ${ }^{82}$ In this example, Jamaican actors both aided 
and discouraged pirates dependent on the impact of piracy on their own activities. Guardships were outfitted to discourage pirates from attacking shipping on local Jamaican coasts, naval vessels were utilised to protect Jamaican vessels engaged in contraband trade on the Honduran coast, while other traders took advantage of the opportunity to gain piratical plunder by trading with pirates operating from the Bay Islands. This was the result of the multifaceted nature of colonial maritime activity in which traders were engaged in a variety of trades occurring at various locales throughout the Atlantic commons whilst state resources were employed to protect profitable colonial trades, and colonial resources were expended to protect local shipping in immediate vicinities.

All of the transactions between pirates and traders outlined here demonstrate the changing nature of plunder markets in the eighteenth century when the plunder trade could no longer be managed in colonial ports. This, in turn, meant that such interactions relied on spontaneous and opportunistic encounters. Indeed, the fact that pirates could no longer expect to receive colonial support or investment at the beginning of voyages but, instead, could only hope to transact with traders after they had plundered desirable goods points to pirates' diminishing options in the early eighteenth century. Nevertheless, although pirates' ability to find willing buyers was never guaranteed, such markets persisted throughout the vast and unpatrolled hinterland of the Atlantic commons wherever there were traders and settlers for whom the benefits of gaining plunder outweighed the risks of trading with pirates. The sustained connections between pirates and colonists within these spaces needs to receive wider recognition within the historiography. Otherwise, the separation of pirates from colonial communities appears much more rigid than it was in reality. This does not refute that perceptions towards piracy changed in the eighteenth century, but that such perceptions were more complex than has been heretofore recognised and this reflects the impromptu 
nature of maritime activity occurring outside of state and colonial centres and beyond the reach of imperial authority.

\section{Dispersing throughout the Atlantic commons}

For the most part, piracy was not expected to be a lifelong occupation but was, instead, part of a long and varied maritime career. McDonald has argued this point, outlining that there was a "spectrum of piracy" which contained, at one end, mariners whose lifetime occupation was piracy and, at the other end, mariners who committed a single act of piracy throughout their career. Found in-between these two extremes were a range of individuals who committed multiple piracies throughout their maritime careers, and who made up the bulk of the population. ${ }^{83}$ Fundamental to this vocational fluidity was that pirates were welcomed back into colonial communities at the end of voyages, where they could then settle down or undertake alternative maritime employment. In the seventeenth century, extensive colonial support of piracy meant that this was an entirely realistic expectation. ${ }^{84}$ However, as open sponsorship of piracy declined in the eighteenth century, so too did pirates' options for reentering colonial society. As Hanna states, "no longer could a successful pirate cruise into the Delaware Bay, dine with the governor, marry his daughter, and settle down to a pleasant life on land." ${ }^{\circledR 5}$ Yet, although pirates could no longer expect to sail into colonial ports and receive welcome from the colonial gentry, they continued to re-enter colonial communities by other means. This was by no means impossible nor exceptional. However, the historiography provides only brief examination of how pirates achieved this, and such discussion focuses on evaluating the success of royal pardons. ${ }^{86}$ Moving beyond state-driven pardons, the detailed evidence surrounding the dispersal of various crewmembers of the Rover after their success on the Brazilian coast provides a unique glimpse into the various strategies that pirates used 
to return to colonial communities. These activities further expose that connections between pirates and landed communities persisted in the eighteenth century, and that such connections regularly exploited the lack of imperial surveillance throughout the Atlantic commons.

Following the capture of the Portuguese ship, Roberts' crew separated into several different groups who concluded their voyages at various different times and places. Roberts and around forty of the crew left the Rover, manned a sloop that had been captured at Salvations' Island, and proceeded in quest of another vessel that had been spotted. This group continued their piratical voyage, committing numerous depredations in the Caribbean, North America, and Newfoundland, before being defeated by the Royal Navy at Cape Lopez on the west coast of Africa in early $1722 .{ }^{87}$ The remaining crew of the Rover, detailed as being between fifty-eight and seventy-six men, sailed from Salvation's Island to Barbados under the command of Walter Kennedy. Near Barbados, Kennedy's crew captured the Eagle and Kennedy transferred into the vessel with forty-seven of the crew; five later joined a Boston brigantine that was headed to Barbados, and the rest directed for Britain, ending up in Craignish. ${ }^{88}$ Of the remaining crew of the Rover, eight took passage on board a trading vessel to Virginia, five were put ashore at Anguilla, and the rest carried the Rover to Saint Thomas. ${ }^{89}$ The multiple conclusions of this voyage demonstrate the methods pirates employed to re-enter landed society and also highlight the varied outcomes of eighteenthcentury piratical voyages. 


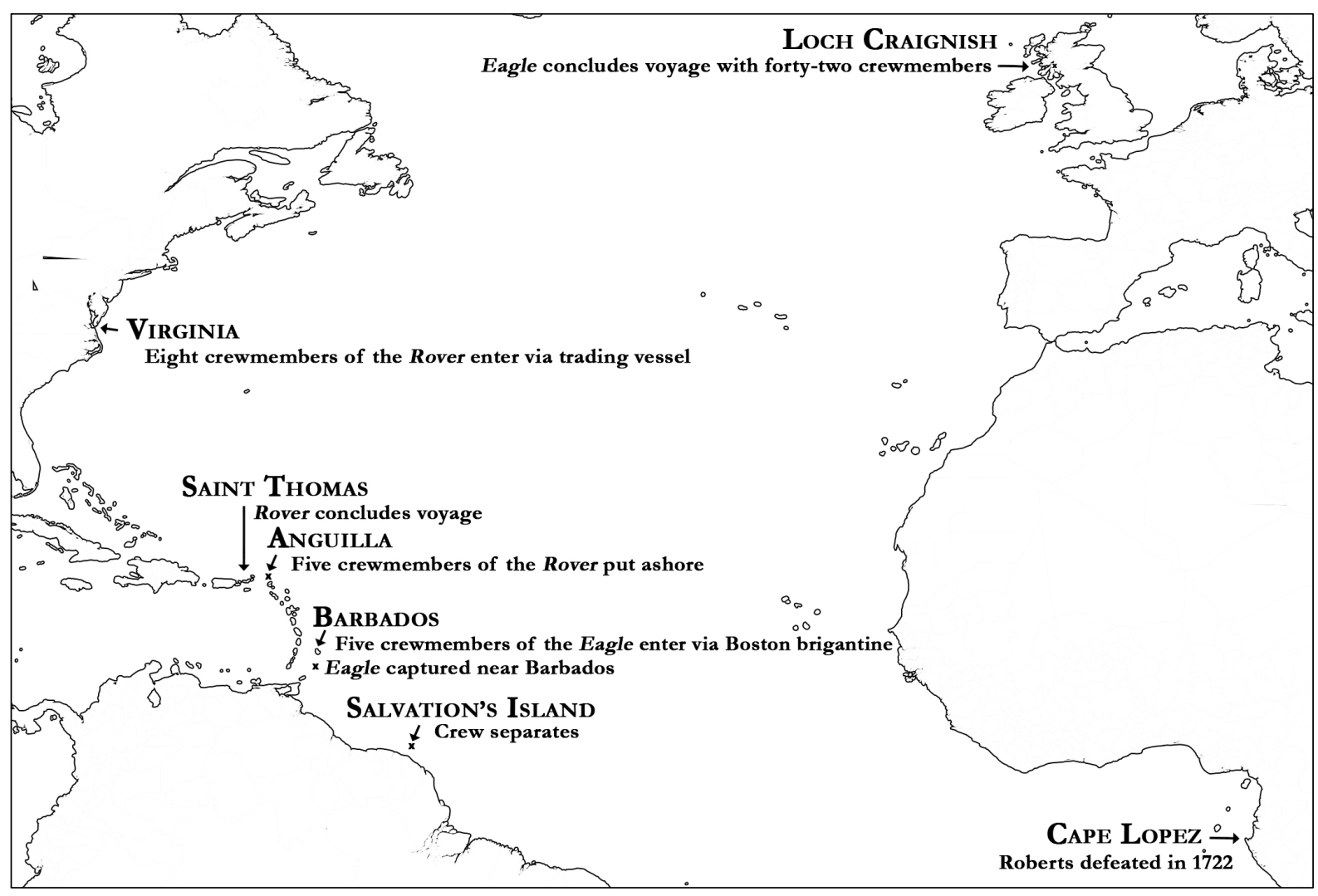

Figure 2. Map showing pirates' dispersal after Salvation's Island

While Roberts' defeat at Cape Lopez in 1722 was a substantial victory for the Royal Navy, it was one of only a handful of naval victories over pirates in the early eighteenth century. In general, the Royal Navy were ineffective in directly suppressing Atlantic piracy. The shortage of naval vessels assigned to extra-European spaces and their overall failure to suppress pirates motivated colonial governments to outfit private vessels in small-scale reactive expeditions with the aim of discouraging pirates impacting local trade. These too achieved few direct successes. Individually, naval and colonial anti-piracy operations enacted little direct change but, collectively, they gradually eliminated a number of Atlantic pirates and created a more hostile environment for pirates to operate within..$^{90}$ Likewise, the public spectacles of pirate executions, the exhibition of convicted pirates' bodies in port towns, and widely publicised and disseminated accounts of the direct successes against pirates presented the potential stakes of committing piracy in order to discourage mariners from turning pirate 
in the future. ${ }^{91}$ Nevertheless, the levels of pirate activity in the early eighteenth century compared to the number of pirates who were caught and convicted suggests that a significant portion of mariners who had sailed on piratical voyages, and who did not die due to disease or conflict, dispersed back into colonial or European communities. ${ }^{92}$ While direct and indirect measures to suppress piracy provided additional motivation for active pirates to disband, it was opportunities within the wider Atlantic commons that facilitated their dispersal.

One means for re-entering landed communities was by obtaining exoneration from colonial governments, either through the blanket pardons intermittently offered by imperial powers or by soliciting for amnesty from potentially welcoming ports. Several pirates accepted the British pardon that was active between September 1717 and July 1719, while others voyaged to French colonies, such as Martinique and Hispaniola, to take advantage of the French pardon that was first offered in 1716 and remained active in the $1720 \mathrm{~s} .{ }^{93}$ Beyond these blanket pardons, pirate crews also sought amnesty at various locations when they intended to disperse. For example, pirates petitioned British naval and colonial officials for individual pardons long after the blanket pardon expired, and at least two crews were granted amnesty by Spanish officials at Cartagena and Portobello. ${ }^{94}$ Similarly, it was suspected that the crewmembers of the Rover who concluded their voyage at Saint Thomas were offered refuge by the Danish settled there. ${ }^{95}$ Nevertheless, exoneration was never guaranteed and, rather than face the risk of being apprehended if communities proved unwelcoming, pirate crews conversed with naval captains and colonial delegates in areas of the Atlantic commons where they could not be easily pursued or apprehended, only entering colonial ports after amnesty had been negotiated. ${ }^{96}$

Amnesty at port cities and settlements for individual pirate crews was offered out of the joint motivation to remove piratical threats and receive influxes of plundered wealth; for example, the pirates who took the pardon at Portobello were required to pay twenty percent 
of their plunder as taxation to the Spanish treasury. ${ }^{97}$ It is uncertain what happened to mariners after accepting amnesty although it is likely that some remained in these regions, perhaps continuing their careers as mariners on board local craft or utilising their plundered wealth in new enterprises, while others took subsequent passage to different colonial or European locales. ${ }^{98}$ As a result of these activities it is clear that, although active pirates were not welcome to operate from colonial ports, landed communities continued to receive pirates and benefit from piratical plunder when pirates retired at the end of their voyage. Yet, there are only a handful of surviving cases of individual pirate crews requesting pardon. Instead, many pirates appear to have simply left their vessels in order to secretly return to colonial communities. To do so, they also exploited opportune spaces and encounters throughout the commons.

As there was little information concerning the vast majority of pirate crewmembers, it was possible to return to landed society without being suspected or caught. ${ }^{99}$ The crewmembers of the Rover and Eagle who transferred to trading vessels encountered at sea and bound for Barbados and Virginia attempted to do exactly that. However, the ability of pirates to successfully disperse in this way relied on the support of the captains and crew of the vessels that they joined. In this case, the crewmembers who had shipped on the Virginianbound vessel were captured after the captain, who had been forced to give the pirates passage, informed the Virginian governor that he had put them ashore within his jurisdiction, whereas those who took passage to Barbados appear to have successfully dispersed. ${ }^{100}$ Other pirates abandoned their ships in order to scatter into peripheral regions with the hope to settle in marginal communities or conceal their past employment and gain passage to their ultimate destinations. ${ }^{101}$ This was precisely what the crewmembers of the Eagle endeavoured when returning to Britain. Indeed, the reason that they had first transferred from the Rover to the Eagle before their homeward-bound voyage was to ensure that they would not be suspected 
as pirates; the Rover was an Ostend ship and it was anticipated that this would raise questions on arrival in Britain. ${ }^{102}$ As the Eagle's crew were predominantly English and Irish, they intended to land quietly on the northern coast of Ireland where it was less likely that they would be spotted or questioned, and then separate in order to find passage to their ultimate destinations throughout England and Ireland. Although not strictly part of the Atlantic commons, the crew planned to utilise the Irish coast in much the same way by landing in an unobserved part of the coast, obscuring their past employment, and journeying to other destinations. Likewise, after being thrown from their intended course by a storm and forced into Loch Craignish on the western coast of Scotland, the crew purposefully grounded the Eagle, split into several groups, and dispersed along different roads in order to seek passage to England and Ireland. ${ }^{103}$ The fact that a number of the crew were arrested whilst hiding in local households makes it apparent that they were aided by members of the local populace who were likely well compensated for their assistance. ${ }^{104}$

While twenty-one of the reported forty-two crewmembers were apprehended in Argyll, the other half successfully dispersed and disappeared. ${ }^{105}$ It is unknown how many pirates scattered into colonial or European societies in the early eighteenth century using similar methods, but it is clear that this was a common practice and it was unlikely that they would be later recognised and apprehended. Of the twenty-one pirates who successfully absconded at Craignish, only two resurfaced at a later point. Walter Kennedy, who had captained the Eagle, and James Bradshaw, who was engaged by the pirates at Anomabu, were arrested in London in 1721 after Kennedy was recognised by a captain whose vessel was plundered in Africa. Although Kennedy provided the names of thirteen other mariners who returned on the Eagle, at least seven of whom were then resident in London, only Bradshaw was arrested. ${ }^{106}$ Of the forty-two crewmembers who returned to Britain in the Eagle: twelve were convicted for piracy, seven were found not guilty, four escaped 
prosecution by turning king's witness, and the remaining nineteen were never caught. Of the twelve convicted, ten were hung and two were spared. ${ }^{107}$

The ability of pirates to return to landed societies, despite the transformation of pirate nests, provides one clear example that European imperial powers lacked the means to effectively police Atlantic maritime activity at an individual level. The opportunity for mobility presented by inter-colonial and inter-imperial interactions in the Atlantic commons meant that there were a variety of options available for mariners to disperse after piratical voyages. This is revealed not just in the endeavours of pirates but by the high mobility that occurred across various groups in the seventeenth and eighteenth centuries. Although state authority did not extend to these areas, the Atlantic commons was not detached from European colonial centres but was instead a crossroads which connected Atlantic polities from established colonial centres, sojourning settlements, and marginal communities, and provided the means for frequent cross-border movement and exchange regardless of formal boundaries or imperial affiliations. Merchants, planters, soldiers, mariners, deserters, and runaway slaves all took advantage of this mobility in order to profit, abscond, or to establish new communities and networks. ${ }^{108}$ Likewise, eighteenth-century pirates returned to landed societies by utilising the opportunities presented by the Atlantic commons. This was achieved by accepting or soliciting amnesty from welcoming colonial communities, by dispersing amongst the largely invisible seafaring populace that roamed the same maritime spaces where pirates plundered and traded, or by disguising their previous employment and returning to colonial or European locales. Whether they succeeded depended on the inclination of communities to accept them or their accomplices' willingness to conceal them, but the fact that a significant portion of pirates succeeded in disbanding and disappearing confirms that there remained a variety of locales where pirates were able to retire with their plunder. 


\section{Conclusion}

Even when they were isolated from colonial port cities in the early eighteenth century, pirates persisted in the maritime spaces in-between colonial centres where state and colonial authority could not extend. Understanding how pirates operated within these locales demonstrates both the structural weaknesses and enduring opportunities of eighteenth-century piracy as their capacity to outfit, trade, and disperse was pushed into the Atlantic commons. Far from being ostracised from landed society entirely, pirates were able to exploit encounters with traders and settlers throughout the Atlantic commons to maintain their connections with colonial communities, whether this was for the purposes of commerce or repatriation. In this way, the Atlantic commons provided the means that sustained and the opportunities that stimulated piratical voyages.

By providing little consideration of the means and methods of eighteenth-century piratical voyages, the existing historiography misrepresents the rigidity of colonial contact with pirates and repeatedly overstates the capacity of imperial authority to police, regulate, or scrutinise Atlantic maritime activity. While colonies became more closely tied to the metropole as they developed beneficial connections and complied with mercantilist policies, this only meant that state authority better extended to the established centres of power in the colonial theatre. It is crucial to recognise that this authority did not, in turn, immediately encompass the detached settlements, sojourning locales, and maritime spaces of the Atlantic commons. Instead, activities in these spaces continued to be dictated by individual agency. The extension and enforcement of metropolitan policies in port towns may have influenced decisions and choices but, ultimately, this was driven by the dispositions of autonomous actors and the opportunities available at any one time. Eighteenth-century piratical voyages echo this reality as they were not an extraordinary feature of the Atlantic world but reflected 
the ad-hoc and often invisible enterprises that drove maritime activity when vessels passed out of sight of colonial shores and beyond the reach of imperial authority. 


\section{Bibliography of Works Cited}

\section{Unpublished Primary Sources}

The National Archives, Kew Gardens (TNA)

$\mathrm{ADM}=$ Records of the Admiralty, Naval Forces, Royal Marines, Coastguard, and related bodies

$\mathrm{CO}=$ Records of the Colonial Office, Commonwealth and Foreign and Commonwealth Offices, Empire Marketing Board, and related bodies

$\mathrm{HCA}=$ Records of the High Court of Admiralty and colonial Vice-Admiralty courts

$\mathrm{T} 70=$ Company of Royal Adventurers of England Trading with Africa and successors:

Records

British Library, London (BL)

IOR $=$ India Office Records and Private Papers

National Records of Scotland, Edinburgh (NRS)

$\mathrm{AC}=$ High Court of Admiralty Records

SC54 = Inveraray Sheriff Court Records

National Register of Archives in Scotland (NRAS)

1209 = Campbell Family, Dukes of Argyll Private Papers (Inveraray, Scotland)

Bank of England Archives, London (BoE)

10A61 = Humphrey Morice Papers

\section{$\underline{\text { Published Primary Sources }}$}

Brock, R. A (ed.). Official Letters of Alexander Spotswood, Vol. II. Virginia: The Virginia Historical Society, 1885.

Johnson, Charles. A General History of the Robberies and Murders of the most notorious Pyrates. London: C. Rivington, 1724.

Redington, Joseph (ed.). Calendar of Treasury Papers, Vol. 6: 1720-1728. London: Her Majesty's Stationery Office, 1889.

Snelgrave, William. A New Account of Some Parts of Guinea and the Slave-Trade. London: James, John, and Paul Knapton, 1734.

\section{$\underline{\text { Secondary Sources }}$}

Anderson, John L. "Piracy and World History: An Economic Perspective on Maritime Predation." In Bandits at Sea: A Pirates Reader, edited by C. R. Pennell, 82-106. New York: New York University Press, 2001.

Baer, Joel. Pirates. Gloucestershire: Tempus Publishing Limited, 2007. 
Barth, Jonathan. "Reconstructing Mercantilism: Consensus and Conflict in British Imperial Economy in the Seventeenth and Eighteenth Centuries." The William and Mary Quarterly 73:2 (April 2016): 257-90.

Bannister, Jerry. The Rule of the Admirals: Law, Custom, and Naval Government in Newfoundland, 1699-1832. Toronto: Osgoode Society for Canadian Legal History, 2003.

Bassi, Ernesto. An Aqueous Territory: Sailor Geographies and New Granada's Transimperial Greater Caribbean World. London: Duke University Press, 2016.

Baugh, Daniel A. "Maritime Strength and Atlantic Commerce: The uses of 'a grand marine empire'." In An Imperial State at War: Britain from 1689-1815, edited by Lawrence Stone, 185-223. London: Routledge, 1999.

Benton, Lauren. "Legal Spaces of Empire: Piracy and the Origins of Ocean Regionalism." Comparative Studies in Society and History 47:4 (Oct, 2005): 700-24.

A Search for Sovereignty: Law and Geography in European Empires, 1400-1900. New York: Cambridge University Press, 2010.

Bialuschewski, Arne. "Pirates, markets and imperial authority: economic aspects of maritime depredations in the Atlantic World, 1716-1726." Global Crime 9:1 (2008): 52-65.

"Between Newfoundland and the Malacca Strait: A Survey of the Golden Age of Piracy, 1695-1725." The Mariner's Mirror 90:2 (2013): 167-86.

Black, Clinton V. Pirates of the West Indies. Cambridge: Cambridge University Press, 1989.

Buchet, Christian. "The Royal Navy and the Caribbean, 1689-1763." The Mariner's Mirror 80:1 (February, 1994): 30-44.

Carter, Marina. "Pirates and Settlers: Economic Interactions on the Margins of Empire." In Fringes of Empire: People, Places, and Spaces in Colonial India, edited by Sameetah Agha and Elizabeth Kolsky, 45-68. Oxford: Oxford University Press, 2009.

Chet, Guy. The Ocean is a Wilderness: Atlantic Piracy and the Limits of State Authority, 1688-1856. Boston: University of Massachusetts Press, 2014.

Cromwell, Jesse. "Covert Commerce: A Social History of Contraband in Venezuela, 17011789.” PhD diss., University of Texas, 2012.

"More than Slaves and Sugar: Recent Historiography of the Trans-imperial Caribbean and Its Sinew Populations." History Compass 12:10 (2014): 770-83.

Dator, James, "Frank Travels: Space, Power and Slave Mobility in the British Leeward Islands, c. 1700-1730." Slavery \& Abolition 36:2 (2015): 335-59.

Dow, George Francis and John Henry Edmonds. The Pirates of the New England Coast, 1630-1730. New York: Dover Publications, Inc., 1996.

Earle, Peter, The Pirate Wars. London: Methuen, 2004. 
Eltis, David and Martin Halbert. Editors. Voyages: The Trans-Atlantic Slave Trade Database. http://www.slavevoyages.org/ (accessed 26 July 2017).

Greene, Jack P. Peripheries and Center: Constitutional Development in the Extended Polities of the British Empire and the United States, 1607-1788. New York: Norton, 1986.

Gosse, Philip. A History of Piracy. New York: Longmans, Green and Co., 1932.

Hancock, David. Oceans of Wine: Madeira and the Emergence of American Trade and Taste. New Haven: Yale University Press, 2009.

Hanna, Mark G. "Well-Behaved Pirates Seldom Make History: A Reevaluation of the Golden Age of English Piracy." In Governing the Sea in the Early Modern Era, edited by Peter C. Mancell and Carole Shammas, 129-168. California: Huntington Library Press, 2015.

Pirate Nests and the Rise of the British Empire, 1570-1740. Chapel Hill: University of North Carolina Press, 2015.

Janzen, Olaf Uwe. "The Problem of Piracy in the Newfoundland Fishery in the Aftermath of the War of the Spanish Succession." In Northern Seas: Yearbook 1997, Association for the History of the Northern Seas, edited Poul Holm and Olaf Uwe Janzen, 57-75. Esbjerg: Association for the History of the Northern Seas, 1998.

Jarvis, Michael J. In the Eye of All Trade: Bermuda, Bermudians, and the Maritime Atlantic World, 1680-1793. Chapel Hill: University of North Carolina Press, 2010.

Kinkor, Kenneth J. "Black Men under the Black Flag." In Bandits at Sea: A Pirates Reader, edited by C. R. Pennell, 195-210. New York: New York University Press, 2001.

Konstam, Angus. Piracy: The Complete History. Oxford: Bloomsburg USA, 2008.

Koot, Christian J. Empire at the Periphery: British Colonists, Anglo-Dutch Trade, and the Development of the British Atlantic, 1621-1713. New York: New York University Press, 2011.

Leeson, Peter T. "An-arrgh-chy: The Law and Economics of Pirate Organization." Journal of Political Economy 115:6 (2007): 1049-94.

Mabee, Bryan. "Pirates, privateers and the political economy of private violence." Global Change, Peace \& Security 21:2 (2009): 139-52.

Mack, Taylor E. "Contraband Trade Through Trujillo, Honduras, 1720s-1782." Yearbook. Conference of Latin Americanist Geographers 24 (1998): 45-56.

McDonald, Kevin P. Pirates, Merchants, Settlers, and Slaves: Colonial America and the Indo-Atlantic World. California: University of California Press, 2015.

Morgan, Kenneth. Slavery and the British Empire: From Africa to America. Oxford: Oxford University Press, 2008.

Mulich, Jeppe. "Microregionalism and intercolonial relations: the case of the Danish West Indies, 1730-1830.” Journal of Global History (2013): 72-94. 
Olson, Alison Gilbert. Making the Empire Work: London and American Interest Groups, 16901790. Cambridge: Harvard University Press, 1992.

Parmentier, Jan. "The Ostend Guinea-Trade (1718-1720)." International Journal of Maritime History 2:1 (June 1990): 175-206.

Perotin-Dumon, Anne. "The Pirate and the Emperor: Power and the Law of the Seas, 14501850.” In Bandits at Sea: A Pirates Reader, edited by C. R. Pennell, 25-54. New York: New York University Press, 2001.

Pincus, Steve. "Rethinking Mercantilism: Political Economy, the British Empire, and the Atlantic World in the Seventeenth and Eighteenth Centuries." The William and Mary Quarterly 69:1 (January 2012): 3-34.

Prado, Fabrício. Edge of Empire: Atlantic Networks and Revolution in Bourbon Río de la Plata. California: University of California Press, 2015.

Rediker, Marcus. "Hydrachy and Libertalia: The Utopian Dimensions of Atlantic Piracy in the Early Eighteenth Century." In Pirates and Privateers: New Perspectives on the War on Trade in the Eighteenth and Nineteenth Centuries, edited by David J. Starkey, E.S. Van Eyck Van Heslinga, J.A. De Moor, 29-46. Exeter: University of Exeter Press, 1997.

- Villains of All Nations: Atlantic Pirates in the Golden Age. London: Verso, 2004.

Ritchie, Robert C. Captain Kidd and the War against the Pirates. Cambridge: Harvard University Press, 1986.

"Government Measures against Piracy and Privateering in the Atlantic Area, 17501850." In Pirates and Privateers: New Perspectives on the War on Trade in the Eighteenth and Nineteenth Centuries, edited by David J. Starkey, E.S. Van Eyck Van Heslinga, J.A. De Moor, 10-28. Exeter: University of Exeter Press, 1997.

Rodger, N. A. M. The Command of the Ocean: A Naval History of Britain, 1649-1815.

London: Penguin Books, 2006.

- "Sea-Power and Empire, 1688-1793." In The Oxford History of the British Empire: Volume II: The Eighteenth Century, edited by P. J. Marshall, Alaine Low, and Wm. Roger Louis, 169-83. Oxford: Oxford University Press, 1998.

Rupert, Linda M. Creolization and Contraband: Curacao in the Early Modern Atlantic World. Georgia: University of Georgia Press, 2012.

Satsuma, Shinsuke. Britain and Colonial Maritime War in the Early Eighteenth Century: Silver, Seapower and the Atlantic. Suffolk: The Boydell Press, 2013.

Soares, Maria João. "The British Presence on the Cape Verdean Archipelago (Sixteenth to Eighteenth Centuries)." African Economic History 39 (2011): 129-46.

Starkey, David J. British Privateering Enterprise in the Eighteenth and Nineteenth Centuries. Exeter: University of Exeter Press, 1990.

"Pirates and Markets." In Bandits at Sea: A Pirates Reader, edited by C. R. Pennell, 107-24. New York: New York University Press, 2001. 
Stern, Philip J. and Carl Wennerlind. Editors. Mercantilism Reimagined: Political Economy in Early Modern Britain and Its Empire. Oxford: Oxford University Press, 2013.

Wilson, David. "Pirates, Merchants, and Imperial Authority in the British Atlantic, 17161726." PhD diss., University of Strathclyde, 2017.

- "Protecting Trade by Suppressing Pirates: British Colonial and Metropolitan Responses to Atlantic Piracy, 1716-1726." In The Golden Age of Piracy: The Rise, Fall, and Enduring Popularity of Pirates, edited by David Head. Georgia: University of Georgia Press, 2018.

Woodard, Colin. The Republic of the Pirates: Being the True and Surprising Story of the Caribbean Pirates and the Man Who Brought Them Down. New York: Harcourt, Inc., 2007.

Yirush, Craig. Settlers, Liberty, and Empire: The Roots of Early American Political Theory, 1675-1775. Cambridge: Cambridge University Press, 2011.

Zahedieh, Nuala. "Trade, Plunder, and Economic Development in Early English Jamaica, 1655-89." The Economic History Review 39:2 (1986): 205-22.

- "The Merchants of Port Royal, Jamaica, and the Spanish Contraband Trade, 16551692." The William and Mary Quarterly 43:4 (1986): 570-93.

- The Capital and the Colonies. Cambridge: Cambridge University Press, 2010.

${ }^{1}$ NRAS, 1209/63. Letter from Campbell, 22 February 1720; NRAS, 1209/197. Memorial \& Queries for the Justiciar \& Sheriff Dept at Argyle, 1720.

${ }^{2}$ For the nineteen confessions see NRAS, 1209/116; NRS, AC 16/1, 384-394; NRS, SC54/17/2/44/1a-1; TNA, HCA 1/54, fols. 121v-122v, 125-125v. See also TNA, HCA 1/54, 121v122v. Examination of Cannady, 28 April 1721.

${ }^{3}$ See Baer, Pirates; Black, Pirates of the West Indies; Dow and Edmonds, Pirates of the New England Coast; Gosse, Piracy; Konstam, Piracy; Woodard, Republic of the Pirates.

${ }^{4}$ See Leeson, "Pirate Organization”, 1049-94; Kinkor, "Black Men under the Black Flag," 195-210; Rediker, Villains of All Nations; Rediker, "Hydrachy and Libertalia," 29-46.

${ }^{5}$ See Anderson, "Piracy and World History," 82-106; Bialuschewski, "Pirates, markets and imperial authority," 52-65; Hanna, Pirate Nests; Ritchie, Captain Kidd; Starkey, "Pirates and Markets", 10724; Zahedieh, "Early English Jamaica,” 205-22; Zahedieh, "The Merchants of Port Royal," 570-93. 
${ }^{6}$ See Bialuschewski, "Pirates, markets and imperial authority", 52-65; Perotin-Dumon, "Pirate and the Emperor," 25-54; Mabee, "The political economy of private violence," 139-52; Starkey, British Privateering; Ritchie, “Government Measures,” 10-28.

${ }^{7}$ Hanna, Pirate Nests.

${ }^{8}$ For recent considerations of mercantilism see Barth, "Reconstructing Mercantilism," 257-90; Pincus, "Rethinking Mercantilism," 3-34; Stern and Wennerlind, "Introduction", 3-22. For colonial compliance and negotiation see Greene, Peripheries and Center; Olson, Making the Empire Work; Yirush, Settlers, Liberty, and Empire; Zahediah, Capital and the Colonies.

${ }^{9}$ Benton, Search for Sovereignty, 104-161; Hancock, Oceans of Wine, xvii-xxv; Jarvis, Eye of All Trade, 185-256; Koot, Empire at the Periphery, 2-14.

${ }^{10}$ Benton, "Legal Spaces of Empire," 706.

${ }^{11}$ For the prevalence of illicit trade see Chet, Ocean is a Wilderness, 66-91; Cromwell, "Covert Commerce," 24-196; Koot, Empire at the Periphery, 181-213; Rupert, Creolization and Contraband, 67-211. For analysis of state and colonial capacity to suppress pirates see Wilson, "Pirates, Merchants, and Imperial Authority"; Wilson, "Protecting Trade by Suppressing Pirates."

${ }^{12}$ Jarvis, Eye of All Trade, 120.

${ }^{13}$ Ibid., 185-256.

${ }^{14}$ Hanna, Pirate Nests, 370.

${ }^{15}$ See Earle, Pirate Wars, 181-208; Hanna, Pirate Nests, 365-415; Rediker, Villains of All Nations, $127-147$.

${ }^{16}$ Chet, Ocean is a Wilderness, 10-1, also 43-50. See also Bialuschewski, "Pirates, markets and imperial authority," 52-65.

${ }^{17}$ In lieu of unpublished sources, researchers often turn to the biographies provided by the pseudonymous Charles Johnson. However, the descriptions he provides are frequently exaggerated, unsubstantiated, and entirely fictional. See Johnson, General History.

${ }^{18}$ Bialuschewski, "Pirates, Merchants, and Imperial Authority," 59-65; Bialuschewski, "Malacca Strait," 176-181; Hanna, Pirate Nests, 366-7. 
${ }^{19}$ For an evaluation of early-eighteenth-century naval campaigns against piracy see Wilson, "Pirates, Merchants, and Imperial Authority." See also Bialuschewski, "Malacca Strait," 173-81; Earle, Pirate Wars, 181-208; Rodger, Command of the Ocean, 232.

${ }^{20}$ Logs kept by Royal Navy captains provide substantial insight into the day-to-day activities of Royal Navy ships in the colonial theatre. See TNA, ADM 51/690, Captain's Logs - Phenix, 8 Oct 1715 to 6 Oct 1721; TNA, ADM 51/672. Captain's Logs, Pearl, 26 July 1715 to 8 December 1719; TNA, ADM 51/4161. Captain's Log - Diamond, 24 May 1723 to 3 Jan 1725.

${ }^{21}$ Woodes Rogers, the governor of the Bahamas, had dispatched the Buck to establish a trade between New Providence and Hispaniola. TNA, CO 23/1, No. 10. Rogers to BOT, 31 October 1718; NRAS, 1209/116. Confession of Hughs, 18 April 1720; NRS, AC16/1, 384-391. Examination of Murray, [1720]; NRS, AC16/1, 384-391. Examination of Murray, [1720]; NRAS, 1209/116. Confession of Hughs, 18 April 1720; TNA, CO 23/12, No. 90ii. Rogers to Newcastle, 26 August 1727.

${ }^{22}$ Soares, "Cape Verdean Archipelago," 138-40.

${ }^{23}$ NRAS 1209/116. Confession of Hughs, 18 April 1720; NRS, AC16/1, 384-391. Examination of Murray, [1720].

${ }^{24}$ British Royal Navy vessels were only dispatched to patrol the African coast after lobbying by metropolitan slave traders concerned with the impact of piracy. TNA, ADM 3/31. Entry 4 February 1719; TNA, ADM 3/32. Entry 18 September 1719; Morgan, Slavery and the British Empire, 62. Although there were European coastal defences in regions outside of the Gold Coast, these were primarily minor fortifications that had often fallen into disrepair and which pirates successfully overcame and destroyed on several occasions. TNA, T 70/6, 97-98. [Mr Plunkett] to RAC, 16 April 1719; NRS, SC54/17/2/44/1a. Confession of Savage, 17 March 1720; NRAS, 1209/116. Confession of Hughs, 18 April 1720.

${ }^{25}$ NRAS, 1209/116. Confession of Haswell, 16 March 1720; NRAS, 1209/116. Confession of Hughs, 18 April 1720; Bialuschewski, "Malacca Strait," 177.

${ }^{26}$ NRAS, 1209/116. Confession of Hughs, 18 April 1720.

${ }^{27}$ Ibid.; NRS, AC16/1, 384-391. Examination of Murray, [1720]. 
${ }^{28}$ NRS, AC16/1, 384-391. Examination of Murray, [1720]; NRAS, 1209/116. Confession of Hughs, 18 April 1720; NRS, AC16/1, 316-324. Indictment of Roger Hews, John Clerk et al.

${ }^{29}$ BoE, 10A61/3. Account of ships taken by pirates at Sierra Leone in April 1719; NRAS, 1209/116. Confession of Haswell, 16 March 1720; NRS, SC 54/17/2/44/1a. Confession of Savage, 17 March 1720; NRS, SC54/17/2/44/1c. Confession of Topen, 18 March 1720; NRS, SC54/17/2/44/1e.

Confession of Dowdoun, 18 March 1720; NRAS, 1209/116. Confession of Clerk, 22 March 1720; NRAS 1209/116. Confession of Hughs, 18 April 1720; NRS, AC16/1, 316-324. Indictment of Roger Hews, John Clerk et al; NRS, AC16/1, 377-381. Information of Duncan Daw; NRS, AC16/1, 381384. Information of Cheap; NRS, AC16/1, 384-391. Examination of Murray, [1720].

${ }^{30}$ TNA, HCA 1/54, 119-119v. Information of Bennett, 28 April 1721.

${ }^{31}$ TNA, T 70/6, 98. Mr. Plunkett to RAC, 16 April 1719; TNA, T 70/6, 97-98. [Mr Plunkett] to RAC, 16 April 1719; TNA, T 70/19, fol. 165. Robert Plunkett to RAC, 30 April 1719; NRS, AC16/1, 316324. Indictment of Roger Hews, John Clerk et al.; 377-381. Information of Duncan Daw; NRS, AC16/1, 381-384. Information of Cheap; TNA, HCA 1/54, 123-123v. Information of Edward Green, 29 April 1721; TNA, HCA 1/55, fol. 5. Information of Stephenson, 9 November 1721.

${ }^{32}$ NRS, SC54/17/2/44/1c. Confession of Topen, 18 March 1720; NRS, SC54/17/2/44/1f. Confession of Ffenton, 19 March 1720.

${ }^{33}$ NRS, SC54/17/2/44/1d. Confession of Setterly, 18 March 1720; NRAS, 1209/116. Confession of Hughs, 18 April 1720.

${ }^{34}$ NRAS, 1209/116. Confession of Hughs, 18 April 1720; NRS, SC54/17/2/44/1b. Confession of Simmonds, 16 March 1720; NRS, SC54/17/2/44/1e. Confession of Dowdoun, 18 March 1720; NRS, SC 54/17/2/44/1g. Confession of Minty, 21 March 1720; NRS, AC9/681. Information for Roger Hews, John Clark et al. against His Majesty's Advocate and the Procurator-Fiscal of the High Court of Admiralty, 14 November 1720; NRS, AC16/1, 384-391. Examination of Murray, [1720].

${ }^{35}$ For examples of resistance and the responses to this see NRS, SC54/17/2/44/1d. Confession of Setterly, 18 March 1720; NRS, SC54/17/2/44/1g. Confession of Minty, 21 March 1720; NRS, SC54/17/2/44/1i. Confession of Thaseter alias Murray, 21 March 1720; NRS, AC16/1, 384-391. Examination of Murray, [1720]. 
${ }^{36}$. TNA, CO 37/10, No. 7. Bennett to BOT, 3 February 1718; TNA, CO 37/10, No. 9. Bennett to BOT, 29 March 1718; TNA, CO 23/1, No. 10. Rogers to BOT, 31 October 1718; NRAS, 1209/116. Confession of Clerk, 22 March 1720; NRAS, 1209/116. Confession of Hughs, 18 April 1720; NRS, AC16/1, 384-391. Examination of Murray, [1720].

${ }^{37}$ TNA, ADM 1/2282. A list of pirates who as surrendered themselves at Providence to Pearse, 3 June 1718

${ }^{38}$ BoE, 10A61/3. Account of ships taken by pirates at Sierra Leone in April 1719; NRS, SC54/17/2/44/1k. Confession of Kernie, 22 March 1720; NRAS, 1209/116. Confession of Hughs, 18 April 1720; NRS, AC16/1, 391-394. Information of Owen.

${ }^{39}$ Bialuschewski, "Malacca Strait," 176-77; Rediker, Villains of All Nations, 137-38; Snelgrave, A New Account, 225.

${ }^{40}$ TNA, ADM 1/2649. Willis to Admiralty, 21 October 1720.

${ }^{41}$ TNA, ADM 1/2453. Memorial of Planters \& Masters at Canteaux, [1724]; Bannister, Rule of the Admirals, 11-2; Janzen, "The Problem of Piracy," 57-75.

${ }^{42}$ For further discussion of forced men and the problems of prosecuting pirates see Benton, "Legal Spaces of Empire," 700-24.

${ }^{43}$ Bialuschewski, "Pirates, Merchants, and Imperial Authority," 59-61; Rediker, Villains of All Nations, 46-48.

${ }^{44}$ NRAS, 1209/116. Confession of Hughs, 18 April 1720; NRS, AC16/1, 384-391. Examination of Murray, [1720]; NRS, AC16/1, 384-391. Examination of Murray, [1720]; NRAS, 1209/116.

Confession of Hughs, 18 April 1720

${ }^{45}$ TNA, CO 23/12, No. 90ii. Rogers to Newcastle, 26 August 1727; Bassi, Aqueous Territory, 47-52; Jarvis, Eye of All Trade, 122-5.

${ }^{46}$ TNA, ADM 1/3810. Memorial of Merchants of London Trading to Africa to Admiralty, 29 July 1720.

${ }^{47}$ This information taken from Voyages: The Trans-Atlantic Slave Trade Database. http://www.slavevoyages.org/voyages/QeLHiq1O (accessed 26 July 2017). 
${ }^{48}$ At Gambia River, the pirates left the Buck and the full crew went on board the King James before proceeding to Sierra Leone. It appears the Buck was given to Edward England. NRS, SC54/17/2/44/1e. Confession of Dowdoun, 18 March 1720; NRAS, 1209/116. Confession of Hughs, 18 April 1719; TNA, HCA 1/54, 114v-115. Information of Creed, 27 September 1720; TNA, HCA 1/54, 115v-116v. Examination of Hunt, 27 September 1720; TNA, HCA 1/54, 119-119v. Information of Bennett, 28 April 1721; TNA, HCA 1/54, 123-123v. Information of Green, 29 April 1721. ${ }^{49}$ Snelgrave, A New Account, 198.

${ }^{50}$ TNA, T 70/6, 97-98. [Mr Plunkett] to RAC, 16 April 1719; NRS, SC54/17/2/44/1a. Confession of Savage, 17 March 1720; NRAS, 1209/116. Confession of Hughs, 18 April 1720.

${ }^{51}$ NRAS, 1209/116. Confession of Hughs, 18 April 1720. The Marquis de Campo originally carried twenty-four cannons so either Hughs was mistaken or it is possible he was referring to the frigate's overall firepower after additional cannons were put on board from the King James. Parmentier, “Ostend Guinea-Trade," 180-1.

${ }^{52}$ NRS, SC54/17/2/44/1g. Confession of Minty, 21 March 1720; NRAS, 1209/116. Confession of Clerk, 22 March 1720.

${ }^{53}$ BL, IOR/E/1/13, No. 99. Deposition of Richard Lasinby, 1722; TNA, HCA 1/55, 94-97. The Examination of Richard Moore, 31 October 1724.

${ }^{54}$ NRAS, 1209/116. Confession of Haswell, 16 March 1720; NRAS, 1209/116. Confession of Hughs, 18 April 1720.

${ }^{55}$ NRAS, 1209/116. Confession of Haswell, 16 March 1720; NRS, SC 54/17/2/44/1a. Confession of Savage, 17 March 1720; NRS, SC54/17/2/44/1c. Confession of Topen, 18 March 1720; NRS, SC54/17/2/44/1e. Confession of Dowdoun, 18 March 1720; NRAS, 1209/116. Confession of Clerk, 22 March 1720; NRAS 1209/116. Confession of Hughs, 18 April 1720; NRS, AC16/1, 377-381. Information of Duncan Daw; NRS, AC16/1, 381-384. Information of Cheap; NRS, AC16/1, 384-391. Examination of Murray, [1720].

${ }^{56}$ NRAS, 1209/116. Confession of Haswell, 16 March 1720; NRAS, 1209/116. Confession of Hughs, 18 April 1720. 
${ }^{57}$ TNA, CO 37/10, No. 10. Bennett to BOT, 31 May 1718; BL, IOR/E/1/12, No. 244. Francis Hastings to the Court of Directors, 19 February 1721, BL IOR/G/17/1 part 1, fols. 52-63. Mocha General Letter to the Court of Directors, 10 July 1721; TNA, HCA 1/55. Information of Joseph Hollet, 13 November 1721; TNA, HCA 1/55. Information of William Voisy, 13 November 1721; BL, IOR/E/1/13, No. 99. Deposition of Richard Lasinby, 1722; TNA, HCA 1/55, 94-97. The Examination of Richard Moore, 31 October 1724.

${ }^{58}$ TNA, CO 152/12, No. 136. Hamilton to BOT, 19 December 1718; TNA, CO 23/12, fols. 28-29v. Rogers to [Craggs], 30 January 1719; TNA, CO 23/1, No. 15. Rogers to BOT, 29 May 1719; TNA, ADM 1/2624. Vernon to Admiralty, 18 April 1721; TNA, ADM 1/1880. Harris to Admiralty, 3 April 1725; TNA, CO 23/1, No. 57i. Deposition of Roger Stevens, 6 May 1725; TNA, CO 23/1, No. 57ii. Deposition of John Ekines, 6 May 1725; Jarvis, Eye of All Trade, 249.

${ }^{59}$ Hancock, Oceans of Wine, xvii-xxv; Koot, Empire at the Periphery, 2-4.

${ }^{60}$ See Jarvis, Eye of All Trade, 249-56; Koot, Empire at the Periphery, 185-91.

${ }^{61}$ TNA, T 70/6, 97-98. [Plunkett] to RAC, 16 April 1719.

${ }^{62}$ BoE, 10A61/3. Account of ships taken by pirates at Sierra Leone in April 1719; NRS, AC16/1, 384391. Examination of Murray, [1720].

${ }^{63}$ BoE, 10A61/1. Snelgrave to Morice, 30 April 1719; TNA, T 70/46, 105. Lynn to Peters, 29

November 1721; Snelgrave, A New Account, 224.

${ }^{64}$ TNA, T 70/6, 98. Plunkett to RAC, 16 April 1719.

${ }^{65}$ BoE, 10A61/1. Snelgrave to Morice, 1 August 1719; TNA, HCA 1/54, 127v-128. Information of Snelgrave, 20 June 1721.

${ }^{66}$ NRS, AC16/1, 384-391. Examination of Murray, [1720].

${ }^{67}$ NRAS, 1209/116. Confession of Hughs, 18 April 1720; NRS, AC16/1, 381-384. Information of Cheap; NRS, AC16/1, 384-391. Examination of Murray, [1720]; Snelgrave, A New Account, 280-4. ${ }^{68}$ NRS, AC16/1, 381-384. Information of Cheap, [1720].

${ }^{69}$ Snelgrave, A New Account, 280-4.

${ }^{70}$ TNA, CO 5/382, No. 18i. Anonymous Letter, August 1716; Boston News-Letter, 24 February 1718; TNA, CO 37/10, No. 38. Hope to BOT, 21 February 1723; TNA, CO 37/26, No. 27. Hope to 
[Carteret], 25 June 1723; TNA, CO 37/11, fols. 113-118v. Hope to BOT, 20 March 1724; TNA, ADM 1/1473. Brand to Admiralty, 23 December 1725; Jarvis, Eye of All Trade, 188-9.

${ }^{71}$ TNA, CO 37/11, fols. 113-118v. Hope to BOT, 20 March 1724.

72 TNA, CO 37/10, No. 38. Hope to BOT, 21 February 1723.

${ }^{73}$ BL, IOR/P/341/5. Bombay Proceedings, Entry 30 January 1721; BL, IOR/E/1/13, No. 97. Account of Richard Lasinby, 19 March 1722; BL, IOR/B/56. Minutes of the Court of Directors, 22 March 1722.

${ }^{74}$ TNA, CO 152/14, fols. 302-305. Hart to BOT, 12 July 1724.

75 'Spotswood to Craggs, 20 May 1720' in Brock (ed.), Official Letters, 340-3.

${ }^{76} \mathrm{BL}, \mathrm{IOR} / \mathrm{D} / 97$. Brittanicus to Heathcote, 6 June 1721; BL, IOR/D/97. Nelson to Cassells, 1 August 1721; TNA, HCA 1/55. Information of Voisy, 13 November 1721; BL, IOR/E/1/12, No. 256.

Chiswell to Directors, 26 November 1721. This was a short-term revival of a similar trade that occurred in the seventeenth-century. See Hanna, Pirate Nests, 183-221; Ritchie, Captain Kidd, 11226.

${ }^{77}$ For further examples, see TNA, ADM 51/690. Captain's Logs - Phenix, 8 October 1715 to 6 October 1721. Entries 22 February 1718, 25 February 1718; TNA, CO 152/12, No. 136i. Deposition of Brown, 12 March 1719; BoE, 10A61/1. Snelgrave to Morice, 30 April 1719; NRS, AC16/1, 391394. Information of John Owen; TNA, CO 37/11, fols. 36-40. Hope to CTP, 14 January 1724.

${ }^{78}$ BL, Add MS 25559, p126-127. Petition of the South Sea Company to the King.

${ }^{79}$ TNA, CO 13714, fols. 184-187. Lawes to CTP, 10 December 1722.

${ }^{80}$ TNA, CO 388/24, No. 145. Merchants trading to Jamaica to CTP, 31 May 1724.

${ }^{81}$ TNA, ADM 1/1880. Harris to Admiralty, 3 April 1725; TNA, CO 23/1, No. 57ii. Deposition of John Ekines, 6 May 1725; TNA, ADM 1/1473. Brand to Admiralty, 4 November 1725; TNA, ADM 1/1473. Brand to Admiralty, 23 December 1725; Brand to Admiralty, 7 April 1726; Mack, "Contraband Trade," 45-8.

${ }^{82}$ TNA, ADM 1/1473. Brand to Admiralty, 21 December 1725.

${ }^{83}$ McDonald, Pirates, Merchants, Settlers, and Slaves, 15.

${ }^{84}$ See Hanna, "Well-Behaved Pirates," 129-68; Hanna, Pirate Nests, 365-70. 
${ }^{85}$ Hanna, Pirate Nests, 366.

${ }^{86}$ Ibid., 368-9; Bialuschewski, "Pirates, Merchants, and Imperial Authority,” 58; Bialuschewski, "Malacca Strait," 176; Chet, Ocean is a Wilderness, 21-2, 48; Earle, Pirate Wars, 189-192; Rediker, Villains of All Nations, 136-7.

${ }^{87}$ TNA, CO 152/14, fols. 33-33v. Deposition of Simes, 21 January 1721; Deposition of Bennett, 24 January 1721; TNA, CO 5/1319, No. 15. Spotswood to BOT, 31 May 1721; TNA, T 70/7, fols. 14-15. Plunkett to RAC, 10 July 1721; TNA, T 70/7, fol. 27. Phipps, Dodson, \& Boye to RAC, 23 April 1722; TNA, ADM 1/2242. Ogle to Admiralty, 26 July 1722.

${ }^{88}$ NRAS, 1209/116. Confession of Haswell, 16 March 1720; NRS, SC 54/17/2/44/1a. Confession of Savage, 17 March 1720; NRS, SC54/17/2/44/1c. Confession of Topen, 18 March 1720; NRS, SC54/17/2/44/1e. Confession of Dowdoun, 18 March 1720; NRS, SC54/17/2/44/1k. Confession of Kernie, 22 March 1720; NRAS, 1209/116; NRAS 1209/116. Confession of Hughs, 18 April 1720; NRS, AC16/1, 377-381.

${ }^{89}$ TNA, CO 152/13, fols. 62-66v. Hamilton to Popple, 16 February 1720; 'Spotswood to Craggs, 20 May 1720' in Brock (ed.), Official Letters, 340-3.

${ }^{90}$ See Wilson, "Pirates, Merchants, and Imperial Authority"; Wilson, "Protecting Trade by Suppressing Pirates." For an evaluation of the Royal Navy in colonial waters see Baugh, "Maritime Strength," 185-223; Buchet, "Royal Navy and the Caribbean," 30-44; Rodger, "Sea-Power and Empire, 1688-1793,” 169-83; Satsuma, Colonial Maritime War.

${ }^{91}$ See Hanna, Pirate Nests, 372-94.

${ }^{92}$ While several hundred pirates were tried and executed during the surge of piracy between 1716 and 1726, Rediker has accounted that the number of pirates active throughout this period was approximately 4,000. Given the fragmentary nature of surviving evidence, such a number has to be regarded as speculative but, even so, this estimate provides a clear indication that there was a significant portion of pirates who were not caught but who simply disappeared from record. Rediker, Villains of All Nations, 29-30, 163.

${ }^{93}$ TNA, CO 37/10, No. 7. Bennett to BOT, 3 February 1718; TNA, CO 37/10, No. 9. Bennett to BOT, 29 March 1718; TNA, CO 23/1, No. 10. Rogers to BOT, 31 October 1718; TNA, CO 137/13, No. 41. 
Bernard to Chetwynd, 4 February 1720; BL, IOR/E/1/13, No. 98. Account of Richard Lasinby, 1722; BL IOR/E/1/13, No. 99. Deposition of Richard Lasinby, 1722; TNA, ADM 1/1880. Harris to Admiralty, 13 October 1722; Carter, "Pirates and Settlers," 60; Bialuschewski, "Malacca Strait," 178. ${ }^{94}$ Two pirate crews unsuccessfully petitioned British colonial officials for amnesty in 1722. TNA, ADM 1/1880. Harris to Admiralty, 17 May 1722; TNA, CO 323/8, No. 35. Harris to Popple, 7 December 1722; TNA, CO 324/11, 3-6. CTP to Privy Council, 10 January 1723; TNA, HCA 1/55, 50v-52v. Examination of Jones, 13 February 1723; TNA, CO 137/52, fol. 47. Portland to Laws, 21 May 1723.

${ }^{95}$ TNA, CO 152/13, fols. 62-66v. Hamilton to Popple, 16 February 1720.

${ }^{96}$ TNA, CO 137/52, fols. 44-44v. Lawes to Portland, 24 April 1723.

${ }^{97}$ BL IOR/E/1/14, No. 163. Extracts of two letters from Pearce to Morice, July 1723; TNA, CO 137/52, fols. 51. President of Panama to the Duke of Portland, 5 October 1723; Carter, "Pirates and Settlers," 60.

${ }^{98}$ BL IOR/E/1/13, No. 99. Deposition of Richard Lasinby, 1722.

${ }^{99}$ Hanna, "Well-Behaved Pirates," 152.

${ }^{100}$ Archibald Murray, who provided the primary evidence against the pirates apprehended in Argyll, was one of the crewmembers who had taken passage to Barbados. NRS, AC16/1, 384-391. Examination of Murray, [1720]; TNA, CO 152/13, fols. 62-66v. Hamilton to Popple, 16 February 1720; American Weekly Mercury (Philadelphia), 17 March 1720; 'Spotswood to Craggs, 20 May 1720’ in Brock (ed.), Official Letters, 340-3; Redington (ed.), Treasury Papers, 134.

${ }^{101}$ TNA, CO 152/13, fols. 62-66v. Hamilton to Popple, 16 February 1720; TNA, HCA 1/55, 50v-52v. Examination of Jones, 13 February 1723; TNA, ADM 1/2242. Orme to Admiralty, 17 May 1723.

${ }^{102}$ NRAS, 1209/116. Confession of Hughs, 18 April 1720.

${ }^{103}$ TNA, HCA 1/54, 125-125v. Examination of Bradshaw, 17 May 1721.

${ }^{104}$ NRAS 1209/116. Confession of John Haswell, 16 March 1720; NRAS 1209/116; NRS SC54/17/2/44/1h. Confession of Richard Lunty, 21 March 1720; Confession of Rodger Hughs, 18 April 1720. 
${ }^{105}$ NRAS, 1209/116. Confession of Haswell, 16 March 1720; NRS, SC 54/17/2/44/1a. Confession of Savage, 17 March 1720; NRS, SC54/17/2/44/1c. Confession of Topen, 18 March 1720; NRS, SC54/17/2/44/1e. Confession of Dowdoun, 18 March 1720; NRAS, 1209/116. Confession of Clerk, 22 March 1720; NRAS 1209/116. Confession of Hughs, 18 April 1720.

${ }^{106}$ It seems that Kennedy and the captain had known each other before their encounter in Africa. TNA, HCA 1/54, 119-119v. Information of Bennett, 28 April 1721; TNA, HCA 1/54, 121v-122v. Examination of Cannady, 28 April 1721; TNA, HCA 1/54, 125-125v. Examination of Bradshaw, 17 May 1721; Rediker, Villains of All Nations, 41.

${ }^{107}$ NRS, AC9/681. List of witnesses against Rogers Hews, John Clerk, et al; NRS, AC16/1, 394-398. Verdict against Roger Hews, John Clerk et al., 17 November 1720; NRS, AC 16/1, 398-400. Verdict against Rogers Hews, John Clerk et al., 22 November 1720; Weekly Journal or British Gazetteer (London), 29 July 1721; Rediker, Villains of All Nations, 41.

${ }^{108}$ For inter-imperial and inter-colonial mobility see Bassi, Aqueous Territory, 23-84; Cromwell, "More than Slaves and Sugar," 770-83; Dator, "Frank Travels," 335-59; Mulich, "Microregionalism and intercolonial relations," 72-94; Prado, Edge of Empire, 131-52. 